\title{
Cytogenetic Studies in North American Minnows (Cyprinidae) XXVI. Chromosomal NOR phenotypes of 21 species from the Western United States
}

\author{
J. D. Jenkin, Y. C. Li, and J. R. Gold \\ Department of Wildlife and Fisheries Sciences, \\ Texas A \& M University, College Station, TX, 77843 U.S.A.
}

Accepted April 24, 1992

Recent cytogenetic studies in our laboratory have focused on identification of nucleolar organizer region (NOR)-bearing chromosomes of North American cyprinid fishes. To date, chromosomal NOR phenotypes have been documented for approximately 80 North American cyprinid species (Amemiya and Gold 1990, Powers and Gold 1992, Li and Gold 1991, Gold et al. 1992, unpubl). Collectively, these studies have demonstrated extensive variation in chromosomal NOR phenotypes among North American cyprinids and shown that chromosomal NOR phenotypes can be utilized as characters for testing or inferring hypotheses of cyprinid relationships (Amemiya and Gold 1988, Amemiya et al. 1992, Powers and Gold 1992). Thus far, all of the cyprinid species surveyed for chromosomal NORs have been from the eastern United States, the region of greatest cyprinid diversification in North America (Mayden 1989, 1991).

In this paper, chromosomal NOR phenotypes of nineteen described and two undescribed cyprinid species from western North America are documented. The cyprinid fauna of western North America is unique in several respects. First, fifteen of the twenty or so cyprinid genera occurring in western North America are monotypic (AFS 1991, Coburn and Cavender 1992) and most are not found east of the Continental Divide (Lee et al. 1980). Secondly, the oldest known cyprinid fossils in North America are from the west and include material from the midto late-Oligocene through the Pliocene and Pleistocene (Uyeno and Miller 1963, Smith 1981, Cavender 1986, 1991). Included among the fossils are several species referable to extent cyprinid genera (e.g., Acrocheilus, Gila, Mylopharodon, and Ptychocheilus). Finally, western North America was a center of extensive tectonic activity (and intermittent aridity) during the late Cenozoic, resulting in a complicated pattern of isolated river basins and numerous interior drainage systems (Miller 1959, Smith 1981, Minckley et al. 1986). This pattern of physiogeographic disruption, coupled with climatic instability, apparently led to increased diversification and extinction of the cyprinid fauna, and has been inferred to be the cause of the high incidence of endemic, species-poor lingeages within individual basins (Miller 1959, Smith 1981). Linkages and faunal transfers among several of the isolated basins, however, must have occurred during this hydrographic history, since several taxa, including the cyprinid genera Gila, Rhinichthys, and Ptychocheilus, are now found throughout much of western North America (Smith 1975, 1981, Minckley et al. 1986).

Perhaps as a consequence of the above, the systematic relationships among western North American cyprinids are not well known. Affinities among a few genera (e.g., Mylopharodon and Mylocheilus, Acrocheilus and Mylopharodon, Mylopharodon and Ptychocheilus, and Hesperoleucas and Lavinia) have been suggested on the basis of morphological and/or allozyme similarities (Miller 1959, Smith 1975, Avise and Ayala 1976). Based primarily on morphological data, Barbour and Miller (1978) and Jensen and Barbour (1981) examined relationships among several species of the Mexican cyprinid genus Algansea, and Woodman (1992) examined 
relationships among species of the genus Rhinichthys. Differing hypotheses of relationships among four species of Ptychocheilus were proposed by Carney and Page (1990) and Mayden et al. (1991). Using a variety of morphological characters, Coburn and Cavender (1992) recently proposed a hypothesis of phylogenetic relationships among most western North American cyprinids. In brief, Coburn and Cavender (1992) identified several putative synapomorphies which united most western North American cyprinids into a monophyletic assemblage. Excluded from this "western" clade were two species of the genus Richardsonius $(R$. balteatus and $R$. egregius) which Coburn and Cavender (1992) placed in the "shiner" clade together with the "notropin" lineage, an assemblage found primarily in eastern North America. Within the western clade, Coburn and Cavender (1992) identified a Gila clade which included the plagopterins (a monophyletic assemblage of three genera from the Colorado River system possessing unique, ossified fin-rays), the paraphyletic (as presently constituted) genus Gila, the Mexican genus Algansea, five monotypic genera, and the genus Rhinichthys. The remaining western cyprinids (referred to as the "California-Columbia" or "basal" group) were placed in a large polytomy basal to the Gila clade. Included in the basal group were several of the genera (i.e., Acrocheilus, Mylopharodon, Ptychocheilus) identified among Pliocene fossils (Miller 1965, Smith 1981, Cavender 1986). The purposes of the present study were to continue sampling chromosomal NOR phenotypes among North American cyprinids and to examine relationships proposed among western North American cyprinids.

\section{Materials and methods}

Seventeen of the western cyprinid species examined in this study were collected by seine from natural populations. The species (collection localities) were as follows: Acrocheilus alutaceus (Umatilla River, Columbia River drainage, Umatilla County, Oregon); Gila (Temeculina) orcutti (Santa Clara River, coastal drainage, Ventura County, California); Gila (Gila) pandora and Rhinichthys cataractae (Guadalupe River, Rio Grande River drainage, Sandoval County, New Mexico); Gila (Temeculina) purpurea (House Pond at Slaughter Ranch, Rio Yaqui draingage, Cochise County, Arizona); Lavinia exilicauda (Putah Creek, Sacramento River draingage, Yolo County, California and Coyote Creek, coastal drainge, Santa Clara County, California); Mylopharodon conocephalus and Ptychocheilus grandis (Pit River, Pit River drainage, Modoc County, California); Orthodon microlepidotus (pond at Ecology Lab Field Station, campus of the University of California at Davis, Sacramento River drainage, Yolo County, California); Ptychocheilus oregonensis (Maries River, Willamette River drainage, Benton County, Oregon); Ptychocheilus umpquae and Richardsonius balteatus (Lookingglass Creek, Umpquae River drainage, Douglas County, Oregon); Ptychocheilus sp. cf umpquae and Rhinichthys sp. cf osculus (Siuslaw River, Siuslaw River drainage, Lane County, Oregon); Rhinichthys (Tiaroga) cobitus (Aravaipa Creek, Gila River drainage, Graham and Pinal Counties, Arizona); Rhinichthys osculus (Bonita Creek, Gila River drainage, Graham County, Arizona); and Richardsonius egregius (Stampede Reservoir, Lahontan drainage, Sierra County, California). Four species (Gila (Gila) elegans, Gila (Gila) nigrescens, Plagopterus argentissimus, and Ptychocheilus lucius) were obtained from the Dexter National Hatchery in Dexter, New Mexico. The origins of parental stocks for the species obtained from the Dexter National Hatchery were as follows: G. elegans (Lake Mohave, Colorado River drainage); G. nigrescens (Mimbras River, Rio Grande River drainage); $P$. argentissimus (Virgin River, Colorado River drainage); and $P$. lucius (Yampa River, Colorado River drainage).

Specimens of $G$. elegans, G. nigrescens, G. orcutti, G. pandora, P. argentissimus, $P$. lucius, $R$. cataractae, $R$. cobitus, and $R$. osculus were returned live to the laboratory and maintained in aerated aquaria until sacrificed. Chromosome preparations from material returned live 
were made either directly from kidney tissues of colcemid- or colchicine-injected specimens (following Gold 1984) or from fibroblast cultures (following Amemiya et al. 1984 as modified by Gold et al. 1990). Direct chromosome preparations from kidney tissues of colchicine-injected specimens were made in-the-field from G. purpurea, L. exilicauda from Putah Creek, and O. microlepidotus. For the remaining specimens (i.e., A. alutaceus, L. exilicauda from Coyote Creek, $M$. conocephalus, $P$. grandis, $P$. oregonensis, $P$. umpquae, $P$. sp. cf umpquae, $R$. sp. cf osculus, $R$. balteatus, and $R$. egregius), small pieces of caudal fin were used to seed fibroblast cultures in-the-field as described in Gold et al. (1990). Voucher specimens for all of the taxa were deposited either in the Texas Cooperative Wildlife Collections (TCWC) at Texas A \& M University or in the University of California at Los Angeles (UCLA) Ichthyological Research Collections. Reference numbers for voucher specimens are listed in the Appendix.

Chromosomal NOR-banding was carried out using the AgNOR procedure of Howell and Black (1980) as modfied by Gold and Ellison (1983). Photomicrographs of silver-stained metaphases were taken using Kodak Technical Pan 2415 film (ASA-25-40) and developed in Diafine (Acufine). Determinations of NOR-band position and relative size and centromere position of NOR-bearing chromosomes were made from positive prints either visually or using a digitizer and the BANDSCAN program described in Gold and Amemiya (1986). Letter designations for NOR chromosome phenotypes followed guidelines in Gold and Amemiya (1986) and Amemiya and Gold (1988).

\section{Results and discussion}

Summary data of the AgNOR-stained material from the 21 species are shown in Table 1; representative silver-stained metaphases are shown in Figs. 1 and 2. All individuals examined possessed $2 \mathrm{n}=50$ chromosomes as do nearly all North American cyprinids (Gold et al. 1980, Ameiya et al. 1992, Powers and Gold 1992, Li and Gold 1991, Gold et al. unpubl). The chromsome numbers of $A$. alutaceus, $G$. elegans, $G$. nigrescens, $G$. pandora, $G$. purpurea, $P$. oregonensis, $P$. umpquae, $P$. sp. cf umpquae, $R$. cobitus, $R$. osculus, $R$. sp. cf osculus, and $R$. balteatus are reported here for the first time. All 21 species possessed multiple NOR-bearing chromosomes (Table 1). Fifteen of the species possessed two pair of NOR chromosomes, four species possessed three pair of NOR chromosomes, and two species possessed four pair of NOR chromosomes. The high incidence of multiple NOR-bearing chromosomes is unusual among North American cyprinids. Of the 80 eastern North American cyprinid species examined prior to this study, $54(67.5 \%)$ possess only a single pair of NOR-bearing chromosomes, $24(30 \%)$ possess two pair of NOR-bearing chromosomes, and two $(2.5 \%)$ possess three pair of NOR-bearing chromosomes (Amemiya et al. 1992, Powers and Gold 1992, Li and Gold 1991, Gold et al. unpubl).

One pair of $A$ NOR chromosomes (NOR terminal on the short arm of a medium-sized acrocentric chromosome) was found in all 21 species, and a second pair of $A$ NOR chromosomes was found in 17 species (Table 1). Twelve species possessed only two pair of $A$ NOR chromosomes. Included among the latter are four of the five genera (i.e., Lavinia, Mylopharodon, Orthodon, and Ptychocheilus) from the basal group (sensu Coburn and Cavender 1992), both species ( $G$. orcutti and G. purpurea) of the subgenus Temeculina of Gila, the lone plagopterin ( $P$. argentissimus) examined, and one species ( $R$. cataractae) of Rhinichthys. One additional pair of $A$ NOR chromosomes was found in $A$. alutaceus, and one pair of $D$ NOR chromosomes (NOR terminal on the short arm of a medium-sized submetacentric chromosome) was found in all three species (G. elegans, G. nigrescens, and G. pandora) of the subgenus Gila of Gila and in $A$. alutaceus. One pair of $F$ NOR chromosomes (NOR terminal on the short arm of a largesized acrocentric chromosome) was found in two species of Rhinichthys (R. cobitus and R.osculus), 
and one pair of $J$ NOR chromosomes (NOR terminal on the short arm of a smll-sized submetacentric chromosome) was found in $R$. cobitus and Richardsonius egregius. One pair of $\boldsymbol{H}$ NOR chromosomes (NOR terminal on one arm of a medium-sized metacentric chromosome) and two pair of $L$ NOR chromosomes (NOR terminal on the long arm of a small-sized submetacentric chromosome) were found in $R$. sp. cf osculus and Richardsonius balteatus, respectively. The occurrence of a NOR on the long arm of a bi-armed chromosome is rare among North American cyprinids, having been documented previously only in Notropis jemezanus (Amemiya and Gold 1988).

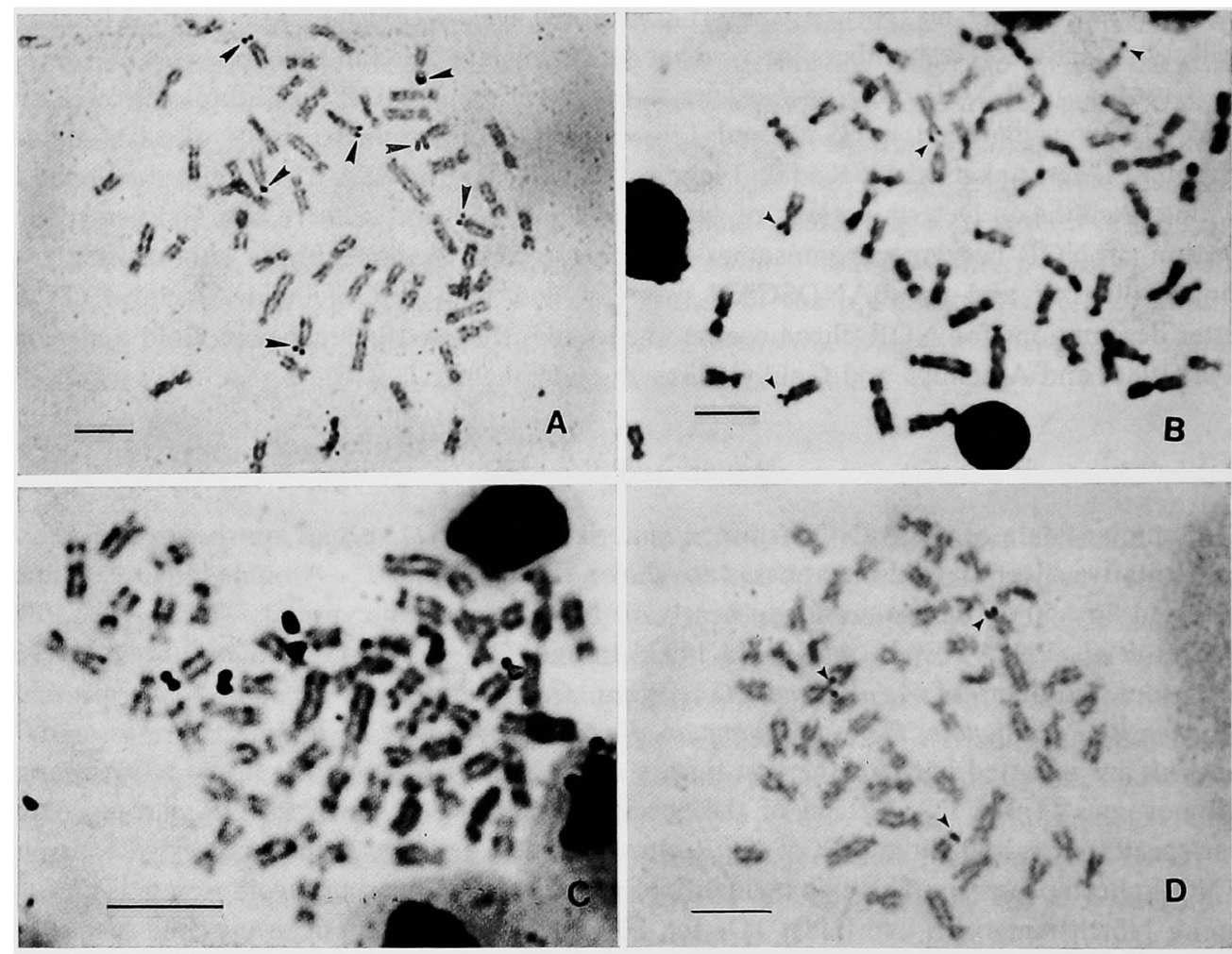

Fig. 1. Silver-stained metaphases of (a) Acrocheilus alutaceus, (b) Gila (Gila) nigrescens, (c) Mylopharodon conocephalus, and (d) Plagopterus argentissimus. Chromosomal NORs are indicated by arrowheads. Bars equal 5 microns.

Among eastern North American cyprinids, $A$ NOR chromosomes have been found only in Campostoma anomalum, a member of the "chub" (sensu Mayden 1989, Coburn and Cavender 1992) clade, and in Notemigonus crysoleucas, the sole endemic North American cyprinid in the Leuciscini (Cavender 1991, Cavender and Coburn 1992). Both the chub clade and Notemigonus would be appropriate outgroups to the western clade (Coburn and Cavender 1992). However, a single pair of $B$ NOR chromosomes (NOR terminal on the short arm of a small-sized acrocentric chromosome) appears to be the plesiomorphic NOR state for the chub lineage (Amemiya and Gold 1990), indicating that the $A$ NOR chromsomes in C. anomalum were independently derived. Alternatively, fifteen of 22 Asian cyprinids examined by Takai and Ojima (1986) possessed NORs that were terminal on the short arm of a small-sized acrocentric chromosome. Assuming that an $A$ NOR state, as found in Notemigonus and Asian cyprinids, is plesiomorphic for North American Cyprinidae, the addition of an $A$ 
NOR chromosome (giving rise to an $A A$ NOR state) is hypothesized to represent a chromosomal synapomorphy uniting the western North American cyprinids into a monophyletic assemblage. This hypothesis is based on the assumption (currently being tested by G-banding) that the different $A$ NOR chromosomes found among the western cyprinids are homologous and on the observation that two pair of $A$ NOR chromosomes are found in all five genera (i.e., Acrocheilus, Lavinia, Mylopharodon, Orthodon, and Ptychocheilus) examined from the basal group (sensu Coburn and Cavender 1992) and in six of the 10 species examined from the Gila clade, i.e., in both species (G. orcutti and G. purpurea) of the subgenus Temeculina of Gila, in P. argentissimus, and in three of the four species examined from the genus Rhinichthys. The finding of two pair of $A$ NOR chromosomes in both species of Richardsonius suggests that Richardsonius

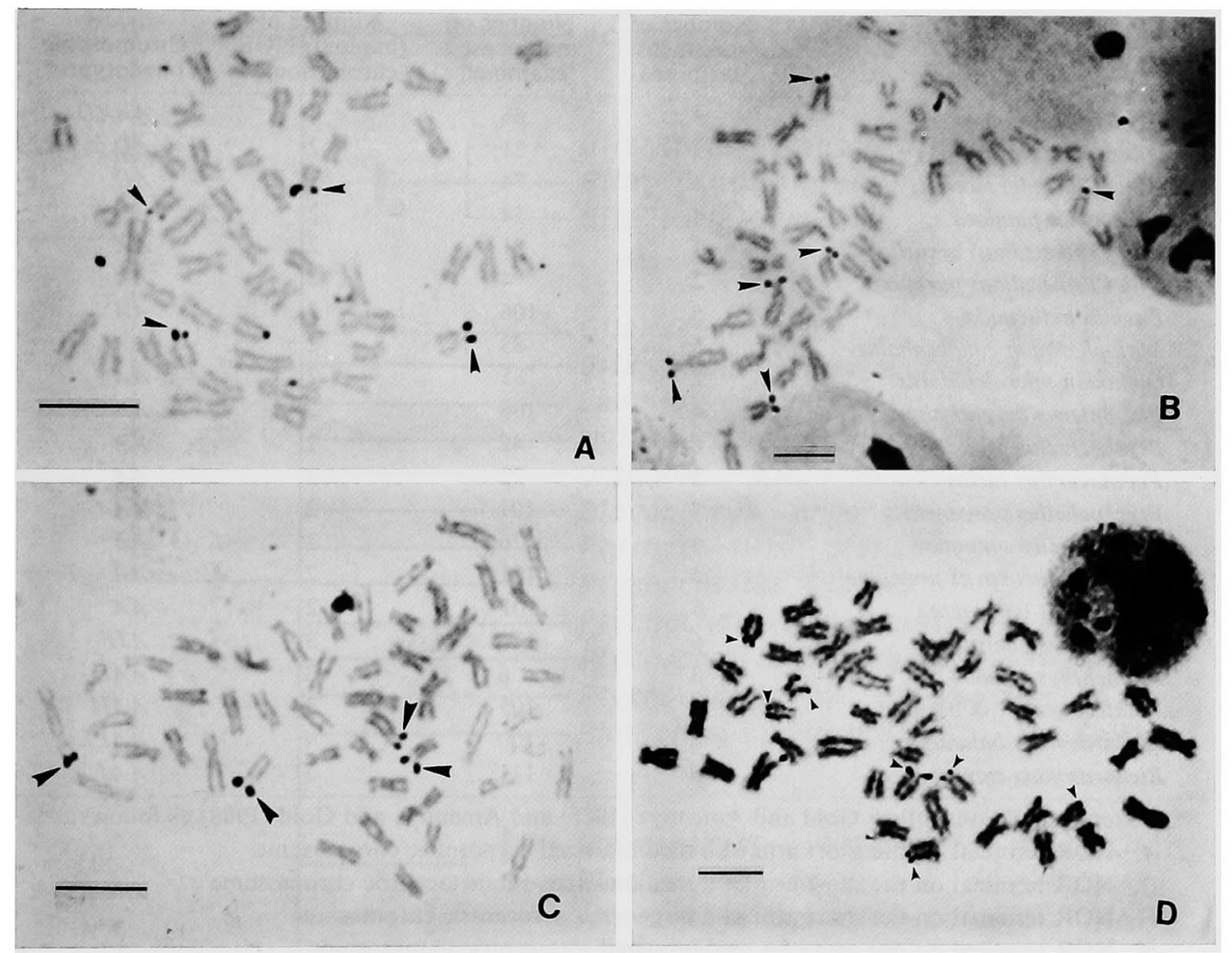

Fig. 2. Silver-stained metaphases of (a) Ptychocheilus grandis, (b) Rhinichthys cobitus, (c) Rhinichthys osculus, and (d) Richardsonius balteatus. Chromosomal NORs are indicated by arrowheads. Bars equal 5 microns.

properly belongs in the western clade and not in the shiner clade as hypothesized by Coburn and Cavender (1992). It should be noted that our hypothesis is predicated, in part, on the basis of commonality.

A working phylogenetic hypothesis for the western clade based on the above is shown in Fig. 3; the $A A$ NOR state is hypothesized to be the plesiomorphic NOR state for the clade. Inferred chromosomal synapomorphies include: (i) the addition of an $F$ NOR, uniting $R$. cobitus and $R$. osculus into a clade; and (ii) a transition from an $A$ NOR chromosome to a $D$ NOR chromosome, uniting the three species of Gila (Gila) into a clade. In both cases, the derived chromosomes (i.e., the $F$ NOR chromosomes in Rhinichthys and the $D$ NOR chromosomes in Gila) are assumed to be homologous. The D NOR chromosome in Acrocheilus and 
the $J$ NOR chromosome in $R$. cobitus are assumed to be non-homologous or homoplasious, respectively, to the $D$ NOR chromosomes in Gila and the $J$ NOR chromosome in $R$. egregius. The remaining derived NOR chromosomes shown in the working hypothesis are assumed to be autapomorphic.

An alternate hypothesis might place the three species of Gila (Gila) outside of the western clade in an dichotomy relative to Notemigonus. This hypothesis would assume an addition of a $D$ NOR chromosome in Gila (Gila) rather than a transition from an $A A$ NOR state to an $A D$ NOR state. This alternate hypothesis seems unlikely given (i) entrenchment of Gila (Gila) within the western clade based on morphology (Coburn and Cavender 1992), and (ii)

Table 1. Summary of NOR-stained material examined

\begin{tabular}{|c|c|c|c|c|}
\hline Taxon & $\begin{array}{l}\text { Number of } \\
\text { specimens } \\
\text { examined }\end{array}$ & $\begin{array}{c}\text { Number of } \\
\text { metaphases } \\
\text { examined }\end{array}$ & $\begin{array}{c}\text { Number of } \\
\text { (haploid) NOR } \\
\text { chromosomes }\end{array}$ & $\begin{array}{l}\text { NOR } \\
\text { chromosome } \\
\text { phenotypes* }\end{array}$ \\
\hline Acrocheilus alutaceus & 3 & 66 & 4 & $A A A D$ \\
\hline Gila (Gila) elegans & 3 & 21 & 2 & $A D$ \\
\hline Gila (Gila) nigrescens & 4 & 74 & 2 & $A D$ \\
\hline Gila (Gila) pandora & 4 & 14 & 2 & $A D$ \\
\hline Gila (Temeculina) orcutti & 3 & 31 & 2 & $A A$ \\
\hline Gila (Temeculina) purpurea & 2 & 4 & 2 & $A A$ \\
\hline Lavinia exilicauda & 5 & 106 & 2 & $A A$ \\
\hline Mylopharodon conocephalus & 3 & 83 & 2 & $A A$ \\
\hline Orthodon microlepidotus & 2 & 85 & 2 & $A A$ \\
\hline Plagopterus argentissimus & 4 & 106 & 2 & $A A$ \\
\hline Ptychocheilus grandis & 6 & 42 & 2 & $A A$ \\
\hline Ptychocheilus lucius & 3 & 22 & 2 & $A A$ \\
\hline Ptychocheilus oregonensis & 7 & 101 & 2 & $A A$ \\
\hline Ptychocheilus umpquae & 4 & 76 & 2 & $A A$ \\
\hline Ptychocheilus sp. cf umpquae & 5 & 101 & 2 & $A A$ \\
\hline Rhinichthys cataractae & 6 & 101 & 2 & $A A$ \\
\hline Rhinichthys cobitus & 6 & 176 & 3 & $A J F$ \\
\hline Rhinichthys osculus & 3 & 6 & 3 & $A A F$ \\
\hline Rhinichthys sp. cf osculus & 3 & 103 & 3 & $A A H$ \\
\hline Richardsonius balteatus & 5 & 100 & 4 & $A A L L$ \\
\hline Richardsonius egregius & 6 & 111 & 3 & $A A J$ \\
\hline
\end{tabular}

* Letter designations follow Gold and Amemiya (1986) and Amemiya and Gold (1988) as follows:

$A$, NOR terminal on the short arm of a medium-sized acrocentric chromosome

$D$, NOR terminal on the short arm of a medium-sized submetacentric chromosome

$F$, NOR terminal on the short arm of a large-sized acrocentric chromosome

$H$, NOR terminal on one arm of a medium-sized metacentric chromosome

$J$, NOR terminal on the short arm of a small-sized submetacentric chromosome

$L$, NOR terminal on the long arm of a small-sized submetacentric chromosome

t Ptychocheilus from the Siuslaw River drainage may merit specific status based in morphometric and genome size (nuclear DNA content) differences (Mayden et al. 1991, Gold et al. unpubl).

apparent G-band homology of the single $A$ NOR chromosome in Gila (Gila) with one of the $A$ NOR chromosomes found in other western cyprinids ( $\mathrm{Li}$ and Gold unpubl.).

The working hypothesis (Fig. 3) is not discordant with the morphological-based hypothesis of relationships among species in the western clade proposed by Coburn and Cavender (1992), although there are no chromosomal synapomorphies supporting monophyly of members of the Gila clade. Monophyly of the three species of Gila (Gila), defined by the transition of an $A \rightarrow D$ NOR, is supported by morphological evidence (Coburn aid Cavender 1992). Monophyly of $R$. cobitus and $R$. osculus relative to $R$. cataractae (defined by the addition of an an $F$ NOR), however, is not supported by morphological evidence (Woodman 1992). Relative 
to the taxa of Rhinichthys examined for chromsomal NORs, Woodman's (1992) morphologically-based hypothesis would be that $R$. cataractae and $R$. cobitus are sister species and that $R$. osculus is sister to a $R$. cataractae- $R$. cobitus clade. The taxon referred to in this paper as $R$. sp. cf osculus is tentatively defined on the basis of an autapomorphic addition of an $H$ NOR chromosome to the presumed plesiomorphic $A A$ NOR state. In brief, specimens of Rhinichthys collected from the Siuslaw River were initially identified in-the field as $R$. osculus.

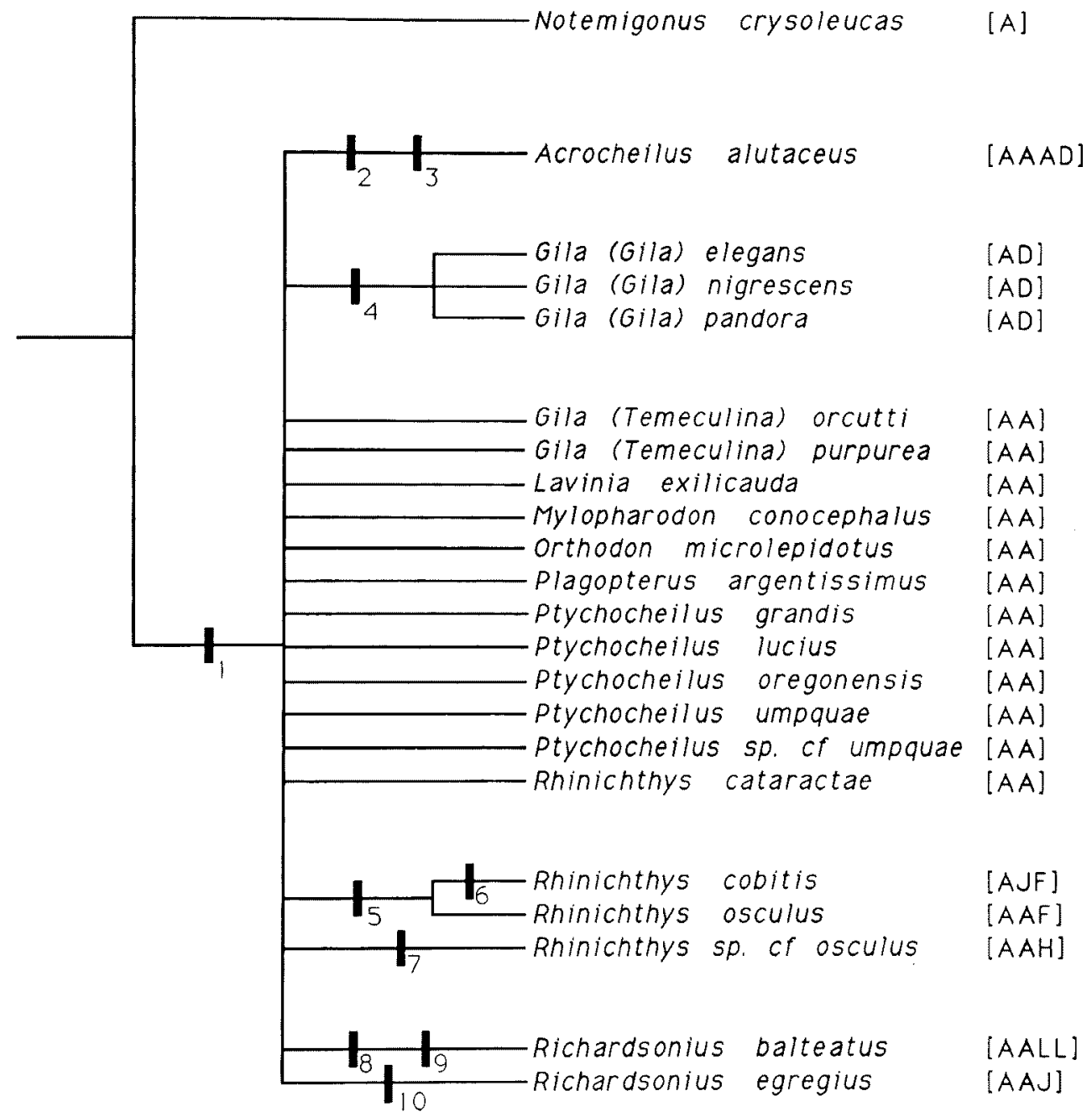

Fig. 3. Phylogenetic hypothesis of relationships among 21 species of western North American Cyprinidae. Presumed chromosomal NOR state changes are (1) $+A,(2)+A,(3)+D,(4) A \rightarrow D$, $(5)+F,(6) A \rightarrow J,(7)+H,(8)+L,(9)+L$, and $(10)+J$.

These specimens differed from $R$. osculus from Bonita Creek in Arizona by the possession of an $H$ NOR chromosome instead of an $F$ NOR chromosome. Careful morphological examination of voucher specimens by W. J. Rainboth of the University of California at Los Angeles (UCLA) indicated that specimens of Rhinichthys from the Siuslaw River were not referrable to either Rhinichthys evermanni or Rhinichthys falcatus, two species of Rhyinichthys which are found in the Umpquae and Columbia river drainages, respectively. Other than differences in 
NOR size and/or apparent transcriptional activity, intraspecific variation in chromosomal NORs is extremely rare in North American cyprinids (Gold and Zoch 1990), suggesting that Rhinichthys in the Siuslaw River may merit specific recognition.

The incidence of interspecific differences in chromosomal NOR phenotypes among western North American cyprinids appears low in comparison to that documented among eastern North American cyprinids. In the latter, differences in chromosomal NOR phenotypes among species within genera and among genera are common. As examples, four different NOR phenotypes occur among 11 assayed species from the genus Cyprinella, four different NOR phenotypes occur among six species assayed from the genus Lythrurus, and five different NOR phenotypes occur among six assayed species from the subgenus Notropis (Amemiya and Gold 1990, Amemiya et al. 1992). The differences among genera are even more striking. $H$ and $C^{\prime}$ NOR chromosome phenotypes predominate in Cyprinella, $F^{\prime} H$ and $F^{\prime} H C$ NOR phenotypes are found in Lythrurus, $C$ and two different $D$ NOR phenotypes occur in the genus Luxilus, and $D, D F$, and $F^{\prime}$ NOR phenotypes are common in the genus Notropis (Amemiya and Gold 1990, Amemiya et al. 1992, Powers and Gold 1992, Gold et al. unpubl). In contrast, most of the observed chromosomal NOR variation in western cyprinids is either concentrated in the genus Rhinichthys or occurs in the form of addition of (autapomorphic) chromosomal NORs (e.g., in Acrocheilus and Richardsonius). The occurrence of the $A A$ NOR phenotype among western cyprinids appears remarkably conserved, being found in seven of the nine genera examined.

Given the antiquity of western North American cyprinids (Uyeno and Miller 1963, Smith 1981, Cavender 1986, 1991), the pattern of chromosomal conservatism in western cyprinids is reminiscent of the "canalization" hypothesis of chromosomal evolution proposed by Bickham and Baker (1979). This hypothesis is based on the idea that the karyotype is strongly affected by natural selection and that chromosomal stability characterizes linesages that have evolved an "optimum" karyotype. The pattern predicted by the hypothesis is that older lineages exhibit greater chromosomal stability at higher taxonomic levels than do younger lineages (Bickham and Baker 1979). Although it can be argued that western cyprinids "fit" the pattern, empirical tests of the tenet that the karyotype is conserved because of strong selection are problematic.

An alternate hypothesis, proposed initially by Smith (1981) on the basis of morphological evidence, relates to the recurrent subdivision and isolation of river basins and drainages which occurred in western North America. In brief, Smith (1981) suggested that increased extinction and reduced speciation resulting from an unstable hydrographic history was accompanied by several instances of apparent character state reversals and introgressive hybridization. Examples of apparent character state reversals in western cyprinids were given in Smith (1981), and examples of possible introgressive hybridization in western catostomids (suckers) were given in Miller and Smith (1981), Smith (1981), Smith et al. (1983), and Crabtree and Buth (1987). Both character state reversals (e.g., reversal to an $A A$ NOR state) and introgressive hybridization (potentially resulting in NOR state homogenization) could explain the chromosomal NOR conservatism observed in western cyprinids. With regard to the latter, examples of interspecific/intergeneric hybridization are common in western cyprinids (Miller 1945, 1963, Hopkirk and Behnke 1966, Smith 1973, 1992), and recent molecular evidence (DeMarais et al. 1992) has demonstrated the apparently successful, historical transfer of mitochondrial (mt)DNA among western cyprinid lineages. There is also strong, suggestive evidence, based on morphology, of intergeneric hybridization between now-extinct species of the cyprinid genera Acrocheilus and Mylocheilus (Smith 1975, 1992). Minimally, the "introgression" hypothesis could provide an explanation for the occurrence of two pair of $A$ NOR chromosomes among most western cyprinids. As with the canalization hypothesis, however, the intro- 
gression hypothesis will be difficult to test empirically.

\section{Summary}

Karyotypes and chromosomal nucleolus organizer region or NOR phenotypes of 19 described and two undescribed species of western North American cyprinids are documented. All 21 species examined possessed $2 \mathrm{~N}=50$ chromosomes and at least two pair of NOR-bearing chromosomes. The high incidence of multiple NOR chromosomes among western cyprinids is unusual. One pair of $A$ NOR chromosomes was found in all 21 species, and 17 species possessed a second pair of $A$ NOR chromosomes. An $A A$ NOR state was hypothesized to represent a chromosomal synapomorphy uniting western cyprinids (including the genus Richardsonius) into a monophyletic assemblage. Within this clade, a transition from an $A$ NOR to a $D$ NOR was hypothesized to represent a chromosomal synapomorphy uniting three speices of the subgenus Gila, and an addition of an F NOR was hypothesized to represent a chromosomal synapomorphy uniting two species of the genus Rhinichthys. Chromosomal NORs in western cyprinids appear conserved relative to eastern cyprinids and may be the result of (i) a process of karyotypic canalization, and/or (ii) character state reversal in, or introgressive hybridization among, western cyprinid genera.

\section{Acknowledgments}

We thank the following individuals for assistance in the procurement and identification of specimens: J. Brooks, B. Burr, D. Buth, B. DeMarais, T. Haglund, B. Jensen, W. Minckley, P. Moyle, S. Platania, and L. Richardson. Special thanks are extended to D. Buth, B. DeMarais, B. Jensen, S. Platania, and W. Minckley for mailing or transporting specimens to Texas, to G. Smith for sending an unpublished manuscript, and to M. Coburn, L. Richardson, and $T$. Schmidt for constructive comments on the manuscript. Work with listed taxa was under federal permit PRT-676811 (to B. L. Jensen and W. L. Minckley) from the United States Fish and Wildlife Service, accompanied by comparable authorizations from the state of Arizona. Work was supported by grants BSR-8415428 and INT-8815517 from the National Science Foundation, and by the Texas Agricultural Experiment Station. Part of the work was carried out in the Center for Biosystematics and Biodiversity, a facility funded, in part, by the National Science Foundation under grant DIR-8907006. This paper represents Contribution $\# 1$ of the Center for Biosystematics and Biodiversity at Texas A \& M University.

\section{Appendix}

Catalogue numbers for voucher specimens deposited in the Texas Cooperative Wildlife Collections (TCWC) are as follows: Gila elegans (6921.01), Gila nigrescens (6584.1), Gila orcutti (6926.01), Gila pandora (6884.02), Gila purpurea (6807.1 and 6584.3), Lavinia exilicauda from Putah Creek (6925.01), Orthodon microlepidotus (6923.01), Plagopterus argentissimus (6921.03), Ptychocheilus lucius (6921.04), Rhinichthys cataractae (6884.01), Rhinichthys cobitus (6919.02), and Rhinichthys osculus from Bonita Creek (6920.01). Catalogue numbers for voucher specimens desposited in the University of California at Los Angeles (UCLA) Ichthyological Research Collection are as follows: Acrocheilus alutaceus (W90-6), Lavinia exilicauda from Coyote Creek (W90-11), Mylopharodon conocephalus (W90-7), Ptychocheilus grandis (W90-7), Ptychocheilus oregonensis (W90-5), Ptychocheilus umpquae (W90-2[A]), Ptychocheilus sp. cf umpquae (W90-3), Rhinichthys osculus from Maries River (W90-5), Rhinichthys sp. cf osculus (W90-3), Richardsonius balteatus (W90-2[A]), and Richardsonius egregius (W90-10). 


\section{References}

AFS 1991. Common and Scientific Names of Fishes from the United States and Canada, Fifth Edition. American Fisheries Society, Special Publication 20, Bethesda, MD.

Amemiya, C. T. and Gold, J. R. 1988. Chromosomal NORs as taxonomic and systematic characters in North American cyprinid fishes. Genetica 76: $81-90$.

- and - 1990. Cytogenetic studies in North American minnows (Cyprinidae). XVII. Chromosomal NOR phenotypes of 12 species, with comments on cytosystematic relationships among 50 species. Hereditas 112: 231-247.

-, Bickham, J. W. and Gold, J. R. 1984. A cell culture procedure for chromosome preparation in cyprinid fishes. Copeia (1984): 232-235.

-, Powers, P. K. and Gold, J. R. 1992. Chromosomal evolution in the North American cyprinids. In "Systematics, Historical Ecology, and North American Freshwater Fishes" (R. L. Mayden, ed.). Stanford Univ. Press, Palo Alto, CA (In Press).

Avise, J. C. and Ayala, F. J. 1976. Genetic differentiation in speciose versus depauperate phylads: evidence from the California minnows. Evolution 30: 46-58.

Barbour, C. D. and Miller, R. R. 1978. A revision of the Mexican cyprinid fish genus Algansea. Misc. Publ. Mus. Zool., Univ. Mich. 155: 1-72.

Bickham, J. W. and Baker, R. J. 1979. Canalization model of chromosomal evolution. Bull. Carnegie Mus. Nat. Hist. 13: 70-84.

Carney, D. A. and Page, L. M. 1990. Meristic variation and zoogeography of the genus Ptychocheilus (Teleostei: Cyprinidae). Copeia (1990): 171-181.

Cavender, T. M. 1986. Review of the fossil history of North American freshwater fishes. In "The Zoogeography of North American Freshwater Fishes" (C. H. Hocutt and E. O. Wiley, eds.), pp. 699-724. John Wiley \& Sons, New York, NY.

- 1991. The fossil record of the Cyprinidae. In "Cyprinid Fishes: Systematics, Biology, and Exploitation" (I. J. Winfield and J. S. Nelson, eds.), pp. 34-54. Chapman \& Hall, London.

- and Coburn, M. M. 1992. Phylogenetic relationships of North American Cyprinidae. In "Systematics, Historical Ecology, and North American Freshwater Fishes (R. L. Mayden, ed.). Stanford Univ. Press, Palo Alto, CA (In Press).

Coburn, M. M. and Cavender, T. M. 1992. Interrelationships of North American cyprinid fishes. In "Systematics, Historical Ecology, and North American Freshwater Fishes" (R. L. Mayden, ed.). Stanford Univ. Press, Palo Alto, CA (In Press).

Crabtree, C. B. and Buth, D. G. 1987. Biochemical systematics of the catostomid genus Catostomus: assessment of C. clarki, C. plebius, and C. discobolus including the Zuni sucker, C. d. yarrowi. Copeia (1987): 843-854.

DeMarais, B. D., Dowling, T. E., Douglas, M. E., Minckley, W. L. and Marsh, P. C. 1992. Origin of Gila seminuda (Teleostei: Cyprinidae) through introgressive hybridization: implications for evolution and conservation. Proc. Natl. Acad. Sci. USA 89: 2747-2751.

Gold, J. R. 1984. Silver-staining and heteromorphism of chromosomal nucleolus organizer regions in North American cyprinid fishes. Copeia (1984): 133-139.

- and Amemiya, C. T. 1986. Cytogenetic studies in North American minnows (Cyprinidae). XII. Patterns of chromosomal NOR variation among fourteen species. Can. J. Zool. 64: 1869-1877.

- and Ellison, J. R. 1983. Silver-staining for nucleolus organizer regions of vertebrate chromosomes. Stain Technol. 58: 51-55.

- and Zoch, P. K. 1990. Intraspecific variation in chromosomal nucleolar organizer regions in Notropis chrysocephalus (Pisces: Cyprinidae). Southwestern Nat. 35: 211-215.

-, Karel, W. J. and Strand, M. R. 1980. Chromosome formulae of North American fishes. Prog. Fish-Cult. 42: $10-23$.

-, Li, Y. C., Shipley, N. S. and Powers, P. K. 1990. Improved methods for working with fish chromosomes, with a review of metaphase chromosome banding. J. Fish Biol. 37: 563-575.

-, Li, Y. C., Birkner, M. C. and Jenkin, J. D. 1992. Chromosomal NOR karyotypes and genome sizes in Dionda (Osteichthyes: Cyprinidae) from Texas and New Mexico. Southwestern Nat. 37: 217-222.

Hopkirk, J. D. and Behnke, R. J. 1966. Additions to the known native fish fauna of Nevada. Copeia (1966): 134-136.

Howell, W. M. and Black, D. A. 1980. Controlled silver-staining of nucleolus organizer regions with a protective colloidal developer: a one-step method. Experientia 36: 1014.

Jensen, R. J. and Barbour, C. D. 1981. A phylogenetic reconstruction of the Mexican cyprinid fish genus 
Algansea. Syst. Zool. 30: 41-57.

Lee, D. S., Gilbert, C. R., Hocutt, C. H., Jenkins, R. E., McAllister, D. E. and Stauffer, J. R., Jr. $1980 . \quad$ Atlas of North American Freshwater Fishes. North Carolina Biol. Surv., Publ. no. 1980-12, Raleigh, NC.

Li, Y. C. and Gold, J. R. 1991. Cytogenetic studies in North American minnows (Cyprinidae). XXII. Chromosomal NORs in the genus Pimephales. Can. J. Zool. 69: 2826-2830.

Mayden, R. L. 1989. Phylogenetic studies of North American minnows, with emphasis on the genus Cyprinella (Teleostei: Cypriniformes). Misc. Publ. 80:1-189, Univ. Kansas Mus. Nat. Hist., Lawrence, KS.

- 1991. Cyprinids of the New World. In "Cyprinid Fishes: Systematics, Biology, and Exploitation (I. J. Winfield and J. S. Nelson, eds.), pp. 240-263. Chapman \& Hall, London.

-, Rainboth, W. J. and Buth, D. G. 1991. Phylogenetic systematics of the cyprinid genera Mylopharodon and Ptychocheilus: comparative morphometry. Copeia (1991): 819-834.

Miller, R. R. 1945. A new cyprinid fish from southern Arizona, and Sonora, Mexico, with the description of a new subgenus of Gila and a review of related species. Copei (1945): 104-110.

- 1959. Origin and affinities of the freshwater fish fauna of western North America. In "Zoogeography". Amer. Assoc. Adv. Sci. Publ. 51: 187-222.

- 1963. Synonymy, characters, and variation of Gila crassicauda, a rare California minnow, with an account of its hybridization with Lavinia exilicauda. Calif. Fish Game 49: $20-29$.

- 1965. Quaternary freshwater fishes of North America. In "The Quaternary of the United States (H. E. Wright, Jr. and D. G. Frey, eds.), pp. 569-581. Princeton Univ. Press, Princeton, NJ.

- and Smith, G. R. 1981. Distribution and evolution of Chasmistes (Pisces: Catostomidae) in western North America. Occ. Pap. Mus. Zool., Univ. Mich. 696: 1-46.

Minckley, W. L., Hendrickson, D. A, and Bond, C. E. 1986. Geography of western North American freshwater fishes: description and relationships to intracontinental tectonism. In "The Zoogeography of North American Freshwater Fishes" (C. H. Hocutt and E. O. Wiley, eds.), pp. 519-613. John Wiley \& Sons, New York, NY.

Powers, P. K. and Gold, J. R. 1992. Cytogenetic studies in North American minnows (Cyprinidae). XX. Chromosomal NOR variation in the genus Luxilus. Copeia (1992): 332-343.

Smith, G. R. 1973. Analysis of several hybrid cyprinid fish from western North America. Copeia (1973): $395-410$.

- 1975. Fish of the Pliocene Glenns Ferry Formation, southwest Idaho. Univ. Mich. Pap. Paleont. $14: 1-68$.

- 1981. Late Cenozoic freshwater fishes of North America. Ann. Rev. Ecol. Syst. 12: 163-193.

- 1992. Introgression in fishes: significance for paleontology, cladistics, and evolutionary rates. Syst. Biol. $41: 41-57$.

-, Hall, J. G., Koehn, R. K. and Innes, D. J. 1983. Taxonomic relationships of the Zuni Mountain sucker, Catostomus discobolus yarrowi. Copeia (1983): 37-48.

Takai, A. and Ojima, Y. 1986. Some features on nucleolus organizer regions in fish chromosomes. In "IndoPacific Fish Biology: Proceedings of the Second International Congress on Indo-Pacific Fishes" (T. Uyeno, R. Arai, T. Taniuchi and K. Matsuura, eds.), pp. 899-909. Ichthylological Society of Japan, Tokyo.

Uyeno, T. and Miller, R. R. 1963. Summary of late Cenozoic freshwater fish records for North America. Occ. Pap. Mus. Zool., Univ. Mich. 631 : 1-34.

Woodman, D. A. 1992. Systematic relationships within the genus Rhinichthys. In "Systematics, Historical Ecology, and North American Freshwater Fishes (R. L. Mayden, ed.). Stanford Univ. Press, Palo Alto, CA (In Press). 